\title{
Los sonetos a la muerte del rayo del septentrión: Lope de Vega y Quevedo sobre Gustavo Adolfo de Suecia
}

\author{
Jacobo Llamas Martínez \\ Universidade de Santiago de Compostela \\ mellamollamass@gmail.com \\ Antonio Sánchez Jiménez \\ Université de Neuchâtel \\ antonio.sanchez@unine.ch
}

Recepción: 13/04/2014, Aceptación: 30/06/2014, Publicación: 17/12/2014

\begin{abstract}
Resumen
El presente artículo estudia la reacción a la muerte de Gustavo Adolfo de dos ingenios del momento, el citado Lope de Vega y Francisco de Quevedo, que escribieron sendos sonetos a la muerte del rey sueco. Al examinar los textos de modo conjunto, descubrimos qué imágenes y estructuras usó respectivamente cada uno de los poetas, y cómo este estilo responde a las emociones que quisieron evocar y a la tradición en la que decidieron inscribirse. Para llevar a cabo este análisis, resumimos en primer lugar las opciones que la tradición de poesía funeral presentaba en el momento, centrándonos luego en la figura de Gustavo Adolfo y en la reacción que suscitó en la época. A continuación, examinamos por turnos los sonetos de Lope —centrándonos en los cambios entre las versiones de 1632 y 1634 - y Quevedo, lo que nos lleva la comparación que es el objeto de nuestro trabajo. Al hacerlo comprobamos que los dos ingenios eligieron en ocasiones imágenes paralelas y, sobre todo, una idea común: la condena del ambicioso monarca sueco en el contexto de un soneto funeral.
\end{abstract}

Palabras clave

Lope de Vega; Francisco de Quevedo; Gustavo Adolfo de Suecia; sonetos; poesía funeral

\begin{abstract}
Sonnets on the Death of the Lion of the North: Lope de Vega and Quevedo on Gustavus Adolphus of Sweden

This articles examines how two Golden Age Spanish writers, Lope de Vega and Francisco de Quevedo, interpreted the figure of king Gustavus Adolphus of Sweden and how they received the news of his death in two sonnets dedicated to it. By examining the
\end{abstract}


texts together, we contrast which images and structures the poets used, and how that style reflected the emotions they wanted to evoke and the tradition in which they chose to inscribe themselves. After a short review of the funeral tradition in poetry, we examine the controversy around Gustavus Adolphus and analyze Lope's sonnet--focusing on the changes between the 1632 and 1634 versions--and Quevedo's. Comparing them, we learn that the two writers chose some parallel images and, above all, the same leitmotiv: a condemnation of ambition.

\section{Keywords}

Lope de Vega; Francisco de Quevedo; Gustavo Adolfo de Suecia; sonnets; funeral poetry

Hubo esta noche luminarias en Madrid y en la Capilla

Real hacimiento de gracias. Y así acabó aquel hereje terror del norte. (León Pinelo, Anales, 294)

Tenemos numerosas noticias acerca del interés con que los españoles áureos seguían las noticias sobre acontecimientos políticos sucedidos lejos de sus fronteras, pero en los que la Monarquía tenía intereses más o menos directos. Sabemos, por ejemplo, que en los años 80 del siglo Xviı los madrileńos estaban tan atentos a las noticias del cerco de Buda y «a las peripecias del sitio y de la toma, como si el Danubio distase de la Villa tan pocas leguas como el Tajo» (Maura Gamazo, 1954: II, 440). Una curiosidad comparable, si no mayor, sentían los madrileños de los años finales de Lope de Vega, cuando los tercios de Felipe IV y sus aliados luchaban por toda Europa en lo que más tarde se conocería como la Guerra de los Treinta Años. Concretamente, uno de los acontecimientos más espectaculares de esta contienda fue la entrada en la guerra de Gustavo Adolfo II de Suecia, en julio de 1630, impulsada por sus fulminantes éxitos iniciales y rematada por su no menos rauda muerte dos ańos más tarde, en la batalla de Lützen, hechos todos que se convirtieron en una "preocupación y tema literario entre los poetas de la corte» (Clavería, 1952: 14). Desde luego la muerte del irredento «hereje terror del norte» también fue motivo general de alegría en Madrid, como demuestra la entrada de los Anales de Antonio de León Pinelo que citamos en el epígrafe. 
El presente artículo estudia la reacción a la muerte de Gustavo Adolfo de dos ingenios del momento, el citado Lope de Vega y Francisco de Quevedo, que escribieron sendos sonetos a la muerte del rey sueco. Al examinar los textos de modo conjunto, descubriremos qué imágenes y estructuras usó respectivamente cada uno de los poetas, y cómo este estilo responde a las emociones que quisieron evocar y a la tradición en la que decidieron inscribirse. Para llevar a cabo este análisis, resumiremos en primer lugar las opciones que la tradición de poesía funeral presentaba en el momento, centrándonos luego en la figura de Gustavo Adolfo y en la reacción que suscitó en la época. A continuación, examinaremos por turnos los sonetos de Lope - centrándonos en los cambios entre las versiones de 1632 y 1634 - y Quevedo, lo que nos llevará a la comparación que es el objeto de nuestro trabajo. Al hacerlo comprobaremos que los dos ingenios eligieron en ocasiones imágenes paralelas y, sobre todo, una idea común: la condena del ambicioso monarca sueco en el contexto de un soneto funeral.

\section{El panegírico funeral de soberanos y militares}

Los sonetos que Lope y Quevedo escriben tras la muerte de Gustavo Adolfo de Suecia responden al modelo del soneto túmulo o soneto epitafio, con el que los autores áureos suelen rendir homenaje a miembros de la realeza, nobles, cortesanos, damas, artistas y otros difuntos, reales o ficticios ${ }^{1}$. Por lo general, los destinados a los monarcas ponderan su valor y fortaleza, rememoran sus triunfos militares y celebran su capacidad para gobernar. Su génesis literaria se puede remontar al epigrama sepulcral y a la elegía de época arcaica, que consolidan un ideal heroico basado en la gloria que proporcionan la lucha y el triunfo ${ }^{2}$. En época helena, este tipo de panegíricos funerales experimenta multitud de imitaciones, adaptaciones eróticas y amorosas, procaces o jocosas, en las que, junto al panegírico de hombres excepcionales, se generaliza el cultivo de textos en los que los fallecidos encarnan valores opuestos a esas virtudes ${ }^{3}$.

1. Para la especialización del soneto como epitafio o túmulo con el que los autores romances tratan de adaptar a las lenguas vernáculas el dístico del epigrama funeral clásico, véase Ángel Estévez Molinero (1996). Ténganse en cuenta también las consideraciones que realiza Juan Matas Caballero (2001) sobre los sonetos escritos tras la ejecución de Rodrigo Calderón y Ponce Cárdenas (2014) sobre el epitafio hispánico durante el Renacimiento.

2. Calino o Tirteo son dos de los primeros poetas de nombre conocido que dedican sus poemas a seres fallecidos; en muchos de ellos exhortan a sus compatriotas a que tomen parte en la guerra para que no mueran en el anonimato y sean recordados por su valor y entrega a la patria. Una reconstrucción de sus composiciones puede leerse en Gabriel Ferraté (1991: 45-49).

3. La Antología palatina y La guirnalda de Filipo contienen parte de estas composiciones. Sagrario López Poza (2005: 15-68) y Lía Schwartz (1993; 1999: 293-324) se ocupan de la difusión de estos textos entre los poetas áureos. Aftonio (Ejercicios de retórica, 243) indica que el vituperio «se divide en los mismos principios de argumentación que el encomio»; Hermógenes (Ejercicios de retórica, 188) explica de forma muy parecida: «No ignores que también unen los vituperios a 
En Roma, las ideas de elogio o censura de gobernantes y militares se diversifican en todo tipo de textos y modalidades: funerales, hímnicos, épicos, elegíacos, históricos o encomiásticos. El panegírico de reyes y emperadores convierte a los gobernantes en paradigma de perfección militar y ética. Sus cualidades evolucionan desde las del ideal del héroe arcaico de fortaleza y valor a las de sabiduría, modestia, honestidad o generosidad, de manera que la grandeza de sus actos va ligada a la excelencia de su espíritu (Claudiano, Panegyricus dictus Probino et Olybrio consulibus, vv.39-44; Pernot, 1993). Los historiadores romanos también recurren a estos aspectos para caracterizar a los personajes principales de sus relatos. Su etopeya depende de la moral y la ética propias del momento y del objetivo o la perspectiva del autor, que los convierte en ejemplos de virtud o de vituperio en función de sus intenciones. Tito Livio, por ejemplo, resalta las cualidades bélicas de Aníbal, pero reprueba su condición moral (Ab vrbe condita, xxI, 4); Salustio (Bellum Catilinae, 5), por su parte, personifica buena parte de los males de su tiempo en la figura de Catilina, al que la nobleza de sus orígenes no le exime de ser, en opinión del historiador, una persona corrupta y viciada.

Estos aspectos se proyectan sobre los textos de carácter bíblico y las literaturas vernáculas europeas. En el medievo, los relatos caballerescos y hagiográficos consolidan el arquetipo de héroe cristiano que a las cualidades de fortaleza, nobleza o sabiduría añade otras virtudes, como la renuncia a los bienes terrenos, fidelidad a Dios o a su señor, que se contraponen con las de villanos y pecadores para agrandar la magnitud de sus hazañas y la ejemplaridad de sus acciones. En el siglo xv castellano, los poetas de cancionero o los autores de biografías y semblanzas también destinan composiciones a reyes y nobles fallecidos. Dependiendo del lugar que ocupan en la corte o de sus propias ambiciones, muestran su afinidad o desacuerdo con decisiones y hechos; los más satisfechos con su posición se dedican a cantar en tono encomiástico los logros de monarcas y nobles vinculados al poder, mientras que aquellos que no ven cumplidas sus expectativas tratan de mostrar su descontento y de desprestigiar a quienes ostentan el poder revelando sus vicios ${ }^{4}$. Algo parecido sucede con ciertas semblanzas y retratos que aparecen en las biografías de hombres ilustres. Víctor García de la Concha

los encomios, bien por denominarlos de modo eufemístico, o porque ambos proceden por los mismos lugares de argumentación». Francisco Rodríguez Adrados (1981: 147) o Bruno Gentili (1996: 254) subrayan la conexión que se da desde época antigua entre la lírica encomiástica y la de escarnio y satírica.

4. En el Laberinto de Fortuna, Juan de Mena, secretario de cartas latinas de Juan II, se sitúa del lado del monarca y de su valido Álvaro de Luna, dirigiendo múltiples alabanzas a sus partidarios y denostando a sus enemigos. Kantorowicz (1985), Nieto (1988) o Morrás (2002) ofrecen una posible lectura política de las composiciones que los poetas de cancionero dirigen a nobles, reyes o duques en su tiempo. García Jiménez (1994: 173) aporta otros matices sobre lo que denomina «elegía épica / elegía servil», que tienen una función claramente social: la de «servir de vehículo de propaganda a la hora de configurar la fama póstuma de personas de elevado rango social». 
(2000: 146) llama la atención sobre Claros varones de Castilla de Fernando del Pulgar, en la que a través del tamiz crítico del retrato, se trata de otorgar a cada individuo «la fama que a cada uno corresponde para que, en definitiva, cada uno ocupe el lugar justo en la historia» ${ }^{5}$.

En el siglo XVI, las composiciones panegíricas de soberanos y militares escritas por los poetas españoles sirven, en su mayoría, para evocar los triunfos de Carlos V, Felipe II y las de sus ejércitos sobre otras naciones europeas que disputan a la corona española la primacía como potencia mundial: franceses, ingleses, protestantes del norte de Europa (holandeses, belgas) u otomanos. En el XVII, en cambio, las composiciones consagradas a título póstumo para Felipe III y sus ejércitos difieren del tono heroico y triunfal de las anteriores. Las dedicadas al monarca tienden a resaltar la piedad de su figura, mientras que algunas de las dirigidas a militares laureados de su corte parecen aludir a los problemas económicos y las dificultades que la coyuntura internacional suponen para el reinado de Felipe $\mathrm{III}^{6}$. De hecho, la amenaza que supone para los intereses de España el poder de los soldados franceses se deja notar en los sonetos que se escriben tras la muerte de Enrique IV, cuyo asesinato tuvo gran repercusión en su tiempo ${ }^{7}$.

\section{Gustavo Adolfo de Suecia y Lützen}

Los sonetos que Lope y Quevedo escriben para Gustavo Adolfo de Suecia más de dos décadas después se sitúan en una órbita parecida a la de los escritos a la muerte de Enrique IV. En ellos se da noticia de su muerte durante la batalla de Lüzten y se traza un sucinto retrato de su figura, que, como suele suceder con la caracterización de otros soberanos en la poesía fúnebre, se apoya en sus actos en vida y en la dimensión moral que se desprende de ellos ${ }^{8}$. Lope y Quevedo

5. Otros detalles sobre el panegírico de héroes y soberanos en Ernst Robert Curtius (1984: 242-252).

6. Quevedo, «Inscripción al marqués Ambrosio Espínola», 10; vv. 9-11: «Todo el Palatinado sujetaste / al monarca español, y tu presencia / al furor del hereje fue contraste». Las citas de los poemas de Quevedo pertenecen a El parnaso español de 1648 del Legado Crosby de la Universidad de Santiago de Compostela. Modernizamos las grafías sin valor fonológico y la puntuación. Sobre la consabida piedad de Felipe III, véase, por ejemplo, el soneto que Quevedo escribe tras su muerte («Mereciste reinar y mereciste», v. 1.) y, sobre todo, el sermón fúnebre que le dirige Francisco de Paravicino, que puede verse en Francis Cerdán (1994: 89-112).

7. Sobre el asesinato de Enrique IV, Quevedo escribió al menos cuatro sonetos y una canción; en todos estos poemas destaca sus valores como militar y el temor que infundía su figura en España e Italia. Lope, Góngora, Villamediana, Salas Barbadillo o Pedro Soto de Rojas también compusieron poemas dedicados a la trágica muerte del monarca francés. Pablo Jauralde (1999: 232, n. 35) ofrece un corpus más completo de ellos, mientras que Ignacio García Aguilar (2009) estudia la reescritura del de Lope entre 1610 y 1627, como veremos abajo.

8. Para el conocimiento de la tradición funeral que Lope y Quevedo demuestran en los sonetos funerales, dedicados a otros soberanos, nobles, militares, damas o cortesanos, puede verse Jacobo Llamas Martínez (2012). 
subrayan así el poder de destrucción de los ejércitos del rey sueco, su ambición y su condición de hereje, que hacen de su muerte en combate un castigo a su imprudencia y falta de piedad.

Hereje o no, pocos personajes merecieron tanto como Gustavo Adolfo composiciones poéticas en este estilo funeral, por la expectación que sus hazañas despertaron entre los españoles del momento. El sueco cambió el curso de la guerra con una intervención con la que no solo infligió severas derrotas a su tradicional enemigo (Dinamarca) y al Imperio, sino que también renovó la táctica militar de la época con actuaciones y organizaciones de gran creatividad. Además, su final, muerto por un arcabuzazo en pleno campo de batalla, resultó tan espectacular como sus victorias y veloz avance hacia el corazón del Imperio. Por ello, aparece con frecuencia en los textos áureos desde 1630, como han notado Luis Rosales y Luis Felipe Vivanco (1943: lx y siguientes), José María Jover (1949: 273 y siguientes; 290) y, sobre todo, Carlos Clavería, quien resume el sentir de la mayoría de los españoles del momento al explicar que Gustavo Adolfo fue «a los ojos de los españoles del siglo XviI, un enemigo odiado, sí, pero siempre un caudillo noble y valeroso", hasta el punto de que si su muerte en Lützen despertó «el júbilo del triunfo", también provocó "consternación y piedad» (1952: 11) . Como hemos adelantado y como veremos abajo en detalle, ni Lope ni Quevedo se dejaron llevar por estos sentimientos, y prefirieron pintar la imagen del horrendo monstruo del norte, seguida de una reflexión general de orden moral.

\section{Lope ante la muerte de Gustavo Adolfo}

Lope menciona a Gustavo Adolfo en tres ocasiones: una carta de c. 1632, el soneto 36 de las Rimas de Tomé de Burguillos y la epístola en liras «Mató su Majestad un venado, y mandó llevar parte dél al P. M. Hortensio, y hallándose allí el licenciado Burguillos partió con él y le envió estos versos», también en las Rimas de Tomé de Burguillos (núm. 167). Nos vamos a centrar en las dos primeras, que contienen dos versiones del soneto que nos interesa, pero antes conviene examinar la de la epístola, que arroja algo de luz sobre las referencias del soneto. Refiriéndose a Felipe IV, a quien miran «el libio» y «el sueco» Gustavo Adolfo, la epístola reza así:

Verdad es que le mira

el libio atentamente, y el süeco

que al de Alemania admira,

de quien nos llega eslabonado el eco

9. Otros estudiosos han llegado a conclusiones similares. Así, Henk Oostendorp estima que el teatro áureo muestra una «mezcla de admiración y aversión» por este «enemigo heroico» (1989: 245). Por su parte, Enrique J. Corredera Nilsson nota un sentimiento semejante en la prosa historiográfica del momento (2009: 164-166). 
que de una en otra nueva

trayendo fama admiraciones lleva ${ }^{10}$. (vv. 49-54)

Ignacio Arellano (2011: 462) ha puesto de relieve la conexión entre esta estrofa y el soneto que nos ocupa, en el que también se menciona la expectación del Emperador (aquí, el «de Alemania»). Asimismo, Arellano ha precisado el sentido del verbo «admirar», que aquí significa 'asustar, preocupar' y carece, por tanto, de connotaciones positivas. De hecho, cabe añadir que el sentido actual de la palabra se debe buscar más bien en el «mira» del primer verso citado, pues aquí son «el libio» y Gustavo Adolfo quienes admiran la grandeza de Felipe IV. Luego, en una figura etimológica, la raíz del verbo se repite en el v. 51 y en el 54, encadenamiento que sugiere la imagen de los vínculos y el eco de la fama, en el v. 52. Esta conexión de fama, miedo, cadena y deseo de emulación, así como la yuxtaposición de Gustavo Adolfo y «el libio» — dos extremos de barbarie en el tórrido sur y el norte helado - nos recuerda que Lope no describe con simpatía al rey sueco. Más bien, Gustavo Adolfo se presenta en el lugar clásico del bárbaro escita, y mantiene una relación con la fama que recuerda más la del infame Eróstrato que la de ninguna figura admirable. Como veremos enseguida, la imagen del sueco en el soneto del Burguillos se mantiene en esta línea.

La primera aparición del soneto se encuentra en una carta a un poeta desconocido que se suele fechar a finales de 1632. La citaremos por extenso porque contiene algunas claves acerca de lo que Lope buscaba con el texto:

Señor mío, ya que es cierta la nueua de la muerte del Rey de Sueçia, enbio a Vm. el soneto, más lleno de miedo de que lleg[u]e a sus manos que salio considerado de las mias [. . . ]. Si mereciere ver el de Vm., le suplico sea seruido de enbiarmele [. . .].

Feroz el sucesor del arrogante

Que fulminó dos vezes Carlos Quinto,

Armado en blanco, aunque pudiera en tinto,

Del Sacro Imperio presumiose Atlante;

Estaua el mundo en acto circunstante

Neutral en boto, en opinión distinto,

Quando cayó de tanto laberinto

Con breue rayo máquina gigante.

Suspendieron la pluma y la g[u]edeja

el Aguila Imperial y el Leon Austrino;

10. Salvo que indiquemos lo contrario, citaremos siempre las Rimas de Tomé de Burguillos por la edición de Antonio Carreño (2002), aunque alterando la numeración de poemas para que coincida con la de las ediciones de Juan Manuel Rozas y Jesús Cańas Murillo (2005) y Macarena Cuiñas Gómez (2008). También adaptamos levemente la puntuación. 
Perdió el temor la sacrosanta Aueja;

Vió mudo al Gallo el Lobo Palatino,

Desplumaron las Aues la Corneja,

$\mathrm{Y}$ al Cesar coronó laurel diuino.

Si le pareziere a Vm. menos graue de lo que pide el sujeto, acuerdese de que siempre tube por infeliz el fin deste hombre, y que, para deçirlo todo sin pesadumbre, me quise balerdeste linaje de estilo, a la usanza de Ytalia.

(Vega Carpio, Epistolario, págs. 148-149)

La noticia tiene en común con la epístola anteriormente citada el elemento documental: en ella volvemos a comprobar el interés con que los madrileños seguían las noticias sobre la guerra de Alemania. Además, añade un elemento nuevo: en primera línea de este batallón de interesados en las nuevas de la Guerra de los Treinta Ańos estaban los poetas, que componían textos encareciendo o lamentando diversos hechos bélicos o políticos. Desde luego, Lope escribió su soneto al confirmarse la noticia de la muerte de Gustavo Adolfo, y su corresponsal hizo lo propio con el suyo, que no se ha conservado.

El soneto en sí lo comentaremos conjuntamente con la versión del Burguillos, pues ahora nos interesa el comentario que acompaña al texto, ya que nos proporciona las preocupaciones del Fénix acerca de su recepción. Meditando sobre ella, Lope anticipa que los lectores podrían encontrar el soneto «menos graue de lo que pide el sujeto", probablemente por el tono y contexto de los tercetos, que remite al mundo de la fábula (política) y que el madrileño justifica explicando que se inspira en "la usanza de Ytalia». Resulta difícil precisar qué modelo concreto tenía Lope en mente, pero no aclarar que el poeta temía que el texto fuera considerado poco decoroso (repetimos: «menos graue de lo que pide el sujeto»), y también demasiado duro ante la muerte de un personaje que, hereje o no, era de sangre real, problema que el Fénix ya había experimentado con su soneto a la muerte de Enrique IV, en 1610 (García Aguilar, 2009). Para evitar que también el relativo a Gustavo Adolfo produjera esa impresión, Lope añade a su carta dos cláusulas muy importantes: «acuerdese de que siempre tube por infeliz el fin deste hombre, y que, para deçirlo todo sin pesadumbre, me quise balerdeste linaje de estilo». Es decir, el Fénix especifica que sintió compasión ante el caso, y que para tratarlo «sin pesadumbre» recurrió a un estro distanciado y festivo. Por tanto, el soneto no comunica "piedad real y 'pesadumbre'", como afirma Clavería (1952: 15), sino más bien los sentimientos opuestos. Por ello Lope trató de moderar el posible efecto del texto con las indicaciones que acabamos de citar.

El propio Clavería considera el poema un «soneto de encargo, escrito con cierta precipitación y dentro de una cierta consciente artificiosidad» (Clavería, 1952: 15), afirmaciones con las que tampoco podemos estar de acuerdo. En primer lugar, no encontramos ningún apoyo para justificar que fuera escrito por encargo. Más bien, de los testimonios se traduce que la muerte del rey sueco 
suscitó el interés de varios poetas y que les movió a escribir versos para celebrar la ocasión. En cuanto a la supuesta precipitación, esa impresión le debe más a los prejuicios en torno a la figura de Lope que al texto en sí. Más bien, la reaparición del poema con notables cambios en las Rimas de Tomé de Burguillos demuestra que al Fénix le interesaba el tema y que trabajó el soneto hasta el último detalle. Por supuesto, el decoro que exigía el tema, del que hemos visto que Lope era muy consciente, pedía la "cierta consciente artificiosidad» que nota Clavería. La sensación de familiaridad y facilidad, la sprezzatura que ostenta el Fénix en otras ocasiones y que tan bien sabía construir, habrían resultado inapropiadas en este contexto. De hecho, y como acabamos de observar, Lope ya estaba bastante preocupado por el decoro del soneto como para emplear un estilo menos elevado y, por tanto, artificioso.

Es más, la versión de 1634, la que publicó en las Rimas de Tomé de Burguillos, presenta alteraciones estilísticas que tiene mucho que ver con esa preocupación. Las vamos a analizar, conjuntamente con la estructura del soneto, a continuación:

El sucesor del gótico arrogante que fulminó dos veces Carlos Quinto, en blanco armado, aunque de sangre tinto, del Sacro Imperio presumiose Atlante.

Estaba el mundo en acto circunstante, si bien el voto universal distinto, cuando cayó de tanto laberinto con breve plomo el ínclito gigante.

Mesurose el león de España, el ave del imperio paró las sacras plumas y el gran Melquisedec doró la llave.

Que suelen de olas infinitas sumas, pensando, altivas, contrastar la nave, nacer montañas y morir espumas. (Arellano, 2012: 78)

De nuevo, el paralelismo con el caso del soneto a Enrique IV que ha estudiado García Aguilar (2009) es perfecto: Lope reescribe e imprime una versión edulcorada de un soneto que había suscitado críticas y quejas por su atrevimiento. Si los sonetos de Enrique IV datan de 1610 y de 1627 (Corona trágica), respectivamente, los que nos ocupan son de 1632 y de dos años más tarde. En ambas versiones del poema sobre Gustavo Adolfo la estructura básica del soneto es idéntica: a unos cuartetos narrativos les suceden dos tercetos que exploran las consecuencias de la muerte del rey. Así, el primer cuarteto presenta la imagen estática de una figura cuasi-titánica, Gustavo Adolfo que se yergue en toda su soberbia. La escena se 
apoya en resonancias míticas que vibran también en el resto del soneto, y que presentan al rey sueco como un titán rebelde contra el poder de Júpiter, que Lope asemeja al del Emperador. Es un subtexto que se sostiene en la palabra "Atlante», que cataliza la constelación de referencias titánicas en el resto del poema. Como aclaró Arellano (2012: 79), «Atlante» alude a la rebelión de los gigantes, pues tiene el valor negativo de 'usurpador', y no el positivo de 'sostenedor', que apuntaba Margarita Cuiñas Gómez (2008: 188). Lope refuerza esa sugerencia mediante la rima, pues «Atlante» rima con «arrogante» (v. 1) y "gigante» (v. 8), que también sostienen la idea de la gigantomaquia. Además, el mundo de los titanes reaparece con la mención de su castigo, fulminados por el rayo de Júpiter: «fulminó» (v. 2) y «breve rayo» (v. 8), que en la versión del Burguillos se transforma en un «breve plomo» que resulta mucho más explícito, pues sirve de metáfora para la bala de arcabuz que acabó con Gustavo Adolfo. Esta escena aparece en el segundo cuarteto, en el que tras dos versos que expresan la expectación universal se narra la caída del gigante, con construcciones que vuelven a evocar la gigantomaquia o, incluso, el castigo del arrogante Faetón, también destruido por un rayo de Júpiter. En suma, los cuartetos presentan el ascenso desafiante del rey sueco y su vertiginosa caída. Primeramente presentan su arrogante imagen en medio de una premonición ominosa que se materializa en los versos 7-8: ya el antepasado de Gustavo Adolfo, Felipe I, landgrave de Hesse y creador de la protestante Liga de Esmalcalda, había sido fulminado por otro emperador/Júpiter, Carlos $\mathrm{V}^{11}$. A continuación, el cuarteto muestra la merecida muerte del arrogante rey.

Precisamente es esa imagen de arrogancia lo que intenta suavizar la reescritura del soneto para las Rimas de Tomé de Burguillos, pues los cambios que presenta la versión de 1634 persiguen ya una elevación del estilo, ya una clarificación de las referencias de la versión de 1632. Así, el primer verso pasa del descarnado comienzo con "feroz» a un adjetivo mucho más sutil ("gótico»), que despierta toda una gama de connotaciones: de barbarie feroz; de nobleza; de identificación con

11. Cuiñas Gómez (2008: 188) piensa que este «gótico arrogante / que fulminó dos veces Carlos Quinto» es Lutero, propuesta cuando menos aventurada, pues ni Gustavo Adolfo fue sucesor de Lutero ni Carlos V fulminó (ni una ni dos veces) al heresiarca. Por su parte, Arellano (2012: 7879) le identifica con Gustavo I de Suecia, Gustavo Vasa, quien según este estudioso «fue detenido por Carlos V» $\mathrm{y}$ "guerreó en varias ocasiones contra los ejércitos del emperador». No nos consta la noticia, ni creemos que le constara al Fénix, pues Gustavo Vasa era una referencia relativamente recóndita en la época. Además, el episodio no parece merecer el verbo "fulminó» que usa Lope. Más bien, el antepasado de Gustavo Adolfo al que se refiere el soneto es el mucho más célebre Felipe I, landgrave de Hesse y gran instigador de la Liga de Esmalcalda (Ávila y Zúñiga, Comentarios, fol. 10v), bisabuelo materno de Gustavo Adolfo. Fue fulminado por Carlos V en Mühlberg, y antes al ponerle en bando imperial como rebelde e invadir sus tierras. La apelación de "gótico» que Lope le otorga en 1634 (no aparece en la versión del Epistolario) puede ser una alusión genérica a la sangre alemana de Felipe, a su mujer, Cristina de Sajonia, o a la ciudad de Gota, que aparece asociada a acciones del landgrave en numerosas ocasiones en los Comentarios de Ávila y Zúniga, que Lope debió de conocer. 
la supuesta esencia de lo español incluso. Además, la referencia a lo gótico aclara el referente, que apunta ahora más abiertamente a los suecos, aunque sea a través de su conexión alemana. Por último, el cambio tiene importantes consecuencias rítmicas: lo que originalmente era un endecasílabo heroico (acentos en las sílabas segunda, cuarta y décima, es decir, 2.4.6.10) se convierte en un sáfico (primer acento en la cuarta sílaba: 4.6.10). El resultado es mucho más armónico y digno, pues permite una clara división del cuarteto en dos grupos de versos rítmicamente idénticos: dos sáficos iniciales (4.6.10) seguidos de dos heroicos (2.4.8.10). En la primera versión el ritmo del verso inicial era, efectivamente, feroz en ese contexto, y le daba al cuarteto una fuerte cadencia yámbica, como de galope o de marcha. Esta cadencia se torna en un ritmo mucho más sutil en la reescritura de 1634. Aunque este del v. 1 es el cambio más llamativo, Lope reescribió también el v. 3, consiguiendo un resultado semejante: dignificación y aclaración. Este verso describe la figura de Gustavo Adolfo — no de su antecesor, como afirma Arellano (2012: 79) ${ }^{12}$ — «armado en blanco» (o «en blanco armado», pues la versión de 1634 se inclina por un elegante quiasmo), ya por estar vestido con la armadura completa ('de punta en blanco'), ya por llevar las armas blancas que correspondían a un caballero novel, pues tal lo era Gustavo Adolfo en el teatro de la guerra alemana. Sin embargo, el cambio mayor se localiza en la segunda parte del verso. Ahí Lope elige un «aunque de sangre tinto» y elimina el "pudiera en tinto». Ese giro era susceptible de una interpretación poco decorosa que quizás no quería evocar el Fénix en 1632, y que debió de tratar de evitar dos años más tarde: la primera versión podría leerse como una alusión al vino y a la supuestamente inmoderada afición del rey y de los tudescos a esta bebida ${ }^{13}$. Finalmente, el v. 8 incluye otro significativo cambio: el «breve rayo» que connotaba el castigo de los titanes se convierte en un «breve plomo», mucho menos críptico. Además, Lope sustituye la palabra «máquina» —que aludía a la maraña o «laberinto» que había creado el ambicioso sueco- por un adjetivo claramente positivo, «ínclito».

En cuanto a los tercetos, tras la narración de los cuartetos, los últimos seis versos presentan la reacción internacional a la muerte de Gustavo Adolfo, mediante una serie de figuras alegóricas que simbolizan diferentes territorios. Aquí las diferencias entre las dos versiones son notables. El soneto del Epistolario sitúa a las entidades enfrentadas en la contienda en dos bandos, cada uno en uno de los tercetos, aunque el último, que reúne los territorios imperiales, se remata con la imagen victoriosa de la coronación del emperador. En cualquier caso, el

12. «Gustavo Vasa se presume 'Atlante del Sacro Imperio' porque pretende dominarlo». Dejando de lado la identificación de este personaje con Gustavo Vasa, que consideramos errónea, la propuesta de Arellano resulta sintácticamente inviable: el que aparece «armado» tiene que ser el sujeto de la oración principal, Gustavo Adolfo, pues si no esa quedaría sin verbo.

13. No creemos que Lope tuviera para los suecos estereotipos muy diferentes de los que utilizaba para caracterizar a los alemanes: rubios, bárbaros y borrachos. 
primer terceto reúne a los máximos representantes del bando imperial: el Emperador ("Águila imperial»), la Monarquía Hispánica («León austrino») y el Papa ( «la sacrosanta Abeja»), referencia esta última al escudo familiar de Urbano VIII (Arellano, 2012: 80). Los mismos protagonistas aparecen en la versión de 1634, aunque con cambios de estilo que responden al consabido intento de ajustar el decoro y clarificar el contenido. Así, el soneto de 1634 elimina la referencia a la "guedeja» del león hispano, que resultaba demasiado pintoresca y que además exigía una rima en «-eja» que rebajaba el tono del poema. Al sustituir esa rima Lope puede aclarar también la referencia al Papa, pues sustituye la imagen del escudo familiar de los Barberini por la de Melquisedec (sumo sacerdote, y por tanto símbolo del Papa [Arellano, 2012: 80]) y la llave de san Pedro. En cuanto a los verbos, también adquieren un tono más digno, encabezados por el «mesurose» del v. 9, y libres ya de la referencia al «temor» (v. 11) de 1632.

El terceto final contiene los cambios más importantes. La versión de 1632 tenía un tono de fábula, pues a los animales heráldicos del bando imperial (águila ${ }^{14}$, león y abeja) se oponían aquí el gallo francés ${ }^{15}$, el lobo del Palatinado ${ }^{16}$ y la corneja sueca. Esta última procede directamente de la fábula esópica del pavo real y la corneja, en la que el córvido intenta imitar al magnífico pájaro vistiéndose plumas ajenas, de las que le despojan, castigándola, el pavo y los otros pájaros ${ }^{17}$. Es una imagen muy claramente negativa del comportamiento de Gustavo Adolfo: Lope interpreta que el sueco ha intentado con su soberbia usurpar la dignidad reservada a las tres grandes potencias del primer terceto, y que su muerte es un castigo ejemplar. La fuerza corrosiva "deste linaje de estilo, a la usanza de Ytalia» (Vega Carpio, Epistolario, 149) desaparece en 1634 para dar lugar a una reflexión moral de orden general, mucho más serena y decorosa que la fábula de 1632. En el Burguillos Lope abandona el campo semántico de los animales y recurre a una bella imagen marítima: la sólida nave asaltada en vano por las altivas olas.

En suma, el análisis de la reescritura del soneto a la muerte de Gustavo Adolfo revela que el Fénix condenó con dureza la actuación del sueco e interpretó su muerte como un castigo divino a su arrogancia titánica. Como sucedió con el soneto a la muerte de Enrique IV en 1610 y 1627, a Lope le preocupó la posibilidad

14. Juan Manuel Rozas (1990: 527) comenta el uso — según él— caricaturesco de este animal heráldico en otro soneto del Burguillos, el número 57.

15. Aunque en 1632 Francia todavía no había entrado en la guerra del lado de las potencias antiimperiales, lo haría en breve, y estaba claro que era solamente una cuestión de tiempo.

16. El escudo del Palatinado no tiene lobos, sino leones, por lo que la referencia al lobo es, más que heráldica, sugestiva de la fiereza del animal. En cualquier caso, Lope era consciente de que la sola mención del lobo no sería suficiente para que sus lectores entendieran que representaba al Palatinado, por lo que aclara «el Lobo Palatino». El Palatinado renano era el territorio que habían invadido las tropas de Gustavo Adolfo para devolvérselo al elector Federico V, calvinista y opuesto al Emperador.

17. La fábula aparece, entre otros muchos lugares, en el Libro de Buen Amor (285-290). 
de comunicar estas ideas sin denigrar la dignidad real del personaje, por lo que incluyó una especie de palinodia en la citada carta de 1632, y realizó en la versión de 1634 diversos cambios que suavizaban, pero no eliminaban, el mensaje. Entre ellos destaca el terceto final, que usaba el desastrado (y merecido) caso del rey sueco para introducir una sentencia moral. Como vamos a explicar a continuación, este mensaje no difiere gran cosa del que al mismo tema le dedicó Quevedo.

\section{El soneto de Quevedo: «Rayo ardiente del mar helado y frío»}

A Quevedo se le pueden atribuir, al menos, unos setenta poemas que consideramos funerales por ser compuestos a título póstumo para seres de existencia real, personajes alegóricos o mitológicos con motivaciones e intenciones muy diversas; a saber, intereses políticos, peticiones expresas, íntimos en señal de agradecimiento, certámenes o para la sátira de tipos, que en el XVII se generalizaron en gran medida en composiciones de tipo panegírico, moral y satírico o burlesco ${ }^{18}$. El dirigido a Gustavo Adolfo, soneto número 25 de «Melpómene», musa tercera de El parnaso español, parece escrito para anunciar la muerte del monarca y para mostrar lo que le puede suceder a cualquier gobernante que trate de oponerse a la voluntad de Dios, representada en la tierra por las tropas de la liga católica ${ }^{19}$ :

Rayo ardiente del mar helado y frío, y fulminante aborto, tendí el vuelo; incendio primogénito del yelo, logré las amenazas de mi brío.

Fatigué de Alemania el grande río; crecile, y calenté con sangre el suelo; azote permitido fui del cielo y terror del augusto señorío.

18. De autoría casi segura son los 35 incluidos en la musa «Melpómene»; los 2 de Clío: «Faltar pudo su patria al grande Osuna» (13); "Ansí, sagrado mar, nunca te oprima» (20); los 2 de Talía: "Yacen en esta rica sepoltura», "Fue más larga que paga de tramposo», el de Euterpe Viéndote sobre el cerco de la luna o los de Urania: «Aqueste es el poniente y el nublado»; "Yace debajo de esta piedra fría»; "La que de vuestros ojos lumbre ha sido»; "Estando solo un día». De atribución más dudosa son algunos otros que circulan en testimonios manuscritos. A este respecto puede verse Alonso Veloso (2008). Excluimos de este cómputo los que aluden a muertes de amor en «Erato".

19. El ms. 5634 de la Biblioteca Nacional de España, ff. 112r-113r, conserva un discurso funeral atribuido al poeta en el que da cuenta de la llegada a Madrid de la noticia de la muerte de Gustavo Adolfo, al que se caracteriza en términos muy parecidos a los del soneto de «Melpómene». Clavería (1952: 11-27), Carmen Peraita (2005: 279) o Manuel Ángel Candelas (2006: 650) ofrecen otros detalles sobre la visión que tiene Quevedo del rey sueco. Luis Astrana Marín (1946: 260263) transcribe una carta en la que Quevedo se refiere a la muerte de Gustavo Adolfo en términos muy parecidos a los de este soneto: «Vivió vencedor y murió vencido [...] Sus heridas serán magnífico epitafio de su sepulcro» (en Astrana Marín, 1946: 263). 
Y bala providente y vengadora,

burlando de mi arnés, defensa vana,

me trujo negro sueńo y postrer hora.

Y, despojo a venganza soberana,

alma y cuerpo, me llora quien me llora;

el que los pierde, ¿qué victorias gana? ${ }^{20}$

Por la condición del personaje, el soneto se puede agrupar junto a los que Quevedo dedica en la musa a monarcas como Felipe III o Enrique IV, y por su caracterización como rey soldado con los dirigidos a los militares Pedro TéllezGirón, Federico y Ambrosio Espínola, Melchor de Bracamonte, Eusebius von Wallenstein, Fadrique de Toledo, el duque de Wallenstein, Aníbal y Aquiles, o el epicedio a Alejandro Magno, que dan muestras de su carácter por sus acciones bélicas. En el primer cuarteto, Quevedo sigue gran parte de los loci a persona dictados fijados por los retóricos helenos para el panegírico: alude al lugar de nacimiento de Gustavo Adolfo —el mar del norte, «mar helado y frío»—; a su linaje — «primogénito» de Carlos IX y Cristina de Holstein-Gottorp- y a su poder y fortaleza («rayo ardiente», "fulminante aborto», «brío») $)^{21}$.

El cuarteto nos da entender que la capacidad bélica («rayo ardiente») y el rápido e inesperado avance («fulminante aborto») del monarca sueco, que se valió («logré») de su fuerza («brío») para cumplir su «amenaza» de ser el primer monarca del norte de Europa («mar helado y frío») en irrumpir en los confines del Sacro Imperio Romano Germánico. Los versos 5 y 6 se hacen eco de los éxitos obtenidos por los ejércitos de Gustavo Adolfo en Alemania, que consiguieron aumentar el poder de su artillería y derribar con facilidad las defensas de las tropas católicas, e ilustran la violencia de sus combates («calenté con sangre el suelo» $)^{22}$. Los versos 7 y 8 avanzan la lectura moral de carácter cristiano de

20. El epígrafe del poema indica: «Lamentable inscripción para el túmulo del rey de Suecia Gustavo Adolfo». González de Salas comenta a continuación: «Después de muchas victorias, murió con una bala peleando en una batalla». En el verso 8 señala: «Es anagramma de Gustavo».

21. Quintiliano (Institutio Oratoria, Laus Hominun, IV, 7,10 ) recomendaba exaltar las hazañas y logros de los individuos elogiados de acuerdo con las noticias que se tienen de ellos y con la circunstancia histórica que les ha tocado vivir. Cicerón, Menandro, Hermógenes o Aftonio coinciden a la hora de señalar que para el elogio de un individuo se ha de aludir, siempre que sea posible, a la nobleza de su cuna, a lo excepcional de su formación, a sus virtudes (sabiduría, fortaleza, honestidad) y a la grandeza de sus acciones: «Basarás los encomios en todos los tópicos panegíricos: familia, nacimiento, naturaleza, crianza, educación, actividades. Dividirás lo de la naturaleza en dos: la belleza del cuerpo — de la que hablarás primero—y las buenas dotes del alma» (Menandro, Tratado II, «Sobre el epitafio», 227).

22. Desde su desembarco en la ciudad de Rügen en junio de 1630, y antes de la muerte del monarca en noviembre de 1632, los ejércitos de Gustavo Adolfo habían conseguido controlar el Danubio y extender su presencia hasta el Báltico. Esta capacidad destructiva le hizo acreedor de los 
los tercetos («azote permitido fui del cielo») y comparan la invasión de los territorios alemanes del Sacro Imperio Romano por parte del rey sueco con las perpetradas por los pueblos bárbaros en tiempos del Imperio Romano ${ }^{23}$.

La relación de hechos de Gustavo Adolfo que nos proporcionan los cuartetos, desde sus orígenes en el Báltico hasta su invasión de la Europa continental, caracterizan al gobernante como un rey de gran poder, pero codicioso y cruel ${ }^{24}$. En los tercetos, esta conducta impía y contraria a los designios divinos hace que el proyectil que le da muerte durante la batalla de Lützen se presente como una condena por hereje y osado. Este terceto se cierra con una alusión a la muerte, entendida como "negro sueño" y "postrer hora», que nos aleja del marco épico de los cuartetos y nos sitúa dentro de una dimensión admonitoria de carácter cristiano ${ }^{25}$.

En el terceto final parece que el espíritu de Gustavo Adolfo acepta el acto de justicia divina que lo condena a la muerte («venganza soberana») y asume las consecuencias de sus actos al cuestionarse de qué le han servido sus triunfos si con ello ha perdido la vida, representada por su cuerpo muerto en el campo de batalla («despojo»).

Así pues, el retrato que traza Quevedo de Gustavo Adolfo de Suecia pondera su capacidad militar, pero censura su condición de hereje y su desmesurada ambición. El soneto retoma muchas de las cualidades señaladas por los retóricos helenos para el encomio - lugar de nacimiento, linaje, acciones que prueban su fortaleza - con otros valores de carácter ético o moral: impiedad, codicia o ambición. De hecho, uno de los mayores méritos de Quevedo, en este y otros sonetos funerales, radica en la armonía con la que, a través del concepto, consigue que atributos guerreros y morales vayan ligados, lo que motiva, además, su estructura argumental ${ }^{26}$.

apelativos de León del norte y Gustavo Adolfo el Grande. Quevedo («Jura del serenísimo príncipe don Baltasar Carlos», v. 186) se refiere a él como «monstro de Estocolmia».

23. Clavería (1952: 13) señala: «Moles [...] ha llamado a Gustavo Adolfo 'trasunto de Totila y Atila, azotes del cielo que invadieron casi toda Europa con temeridad y violencia’». La asociación con Atila recuerda las connotaciones luciferinas y titánicas que cobraba la figura de Gustavo Adolfo en el soneto de Lope.

24. Quevedo se hace eco nuevamente así de las indicaciones de retóricos como Hermógenes (Ejercicios de retórica, 189): «Lo más importante son las acciones, pues las acciones dependen de las ocupaciones; si eligió la vida militar, ¿qué actos llevó en esta?».

25. Quevedo combina la noción de sueńo, oscuridad y momento final para referirse a la muerte en el «Epitafio del sepulcro del duque de Osuna», 5: «Hasta que, apresurado el postrer sueño, / le ennegreció con noche el blanco día». En su poesía moral, el poeta también asocia este tipo de referentes: "dentro del corazón el postrer día; / y la última hora, negra y fría» («Polimnia», «Conoce la diligencia con que se acerca la muerte», 62; vv. 2-3). Para una posible explicación de estos términos, consúltese Arellano y Schwartz (1998: 820). La creencia de que los muertos dormían es muy antigua; ya en el hades homérico los difuntos eran «un pueblo apagado, fantasmas de los humanos agotados, que duermen en la muerte»; véase Philippe Ariès (1983: 27-29) o Margaret Alexiou (1974: 189-93).

26. Para la organización interna del soneto como forma estrófica en Quevedo, consúltense Antonio García Berrio (1982), Manuel Ariza (1984), Marie Roig Miranda (1989: 273-283), Antonio Azaustre (1996) o José María Pozuelo (1999). La dispositio de los poemas de los siglos XVI y XVII 
Por lo general, en los sonetos funerales de Quevedo nos encontramos poemas de tipo laudatorio o vituperativo. Los primeros, que son la mayoría, muestran ejemplos de virtud en los que la laudatio vertebra la composición y aglutina los esfuerzos creativos del autor. En este tipo de sonetos, el elogio del fallecido suele presentarse desde el primero de los cuartetos. El encomio conduce al lamento y al consuelo: al lamento, porque cuanto mayor es la virtud del difunto, mayor es la pena que deja en la tierra; al consuelo, porque esta virtud será también la que haga merecedor al muerto de su acceso a la gloria, la que le permita perpetuarse en la memoria de los hombres y en sus descendientes ${ }^{27}$. En ocasiones, debido a la concisión del soneto, no es posible discernir con nitidez alguna de estas tres esferas (elogio, lamento y consuelo), que pueden subsumirse en las otras dos o llegar incluso a elidirse. Lo habitual es que Quevedo omita las manifestaciones de dolor o de duelo, de manera que su visión coincide con el espíritu contrarreformista, que recomendaba reducir este tipo de expresiones y recibir la muerte como celebración de la vida eterna. Con todo, la primacía de los asuntos panegíricos hace que en algunos versos el lamento se explicite como parte de la alabanza del difunto ${ }^{28}$. En ciertos sonetos, además, puede reservarse el último terceto, o alguno de sus versos, para interponer una especie de epifonema conclusivo que concentra mayor grado de elaboración en sus agudezas ${ }^{29}$.

El soneto para Gustavo Adolfo de Suecia pertenece a los sonetos funerales de carácter vituperativo, aquellos en los que Quevedo censura la conducta y la vileza moral de ciertos difuntos, como la del propio monarca sueco o el duque de Wallenstein, composición que, curiosamente, se sitúa en «Melpómene» a conti-

puede examinarse desde diversas perspectivas, aunque todas ellas tienen en cuenta elementos estróficos, retóricos y temáticos. En el Cisne de Apolo, III, 18, Carvallo señalaba cuatro componentes principales del epitafio fúnebre: «mover a lástima, dar ejemplos, alabar al difunto y declarar el nombre de la persona enterrada para identificarlo». De estos aspectos también se ocupan Rosa María Lida de Malkiel (1941: 159), Eduardo Camacho Guizado (1969: 21), William H. Race (1988: 86-117) o Laurent Pernot (1993: 135-178). Para la semejanza de esta disposición con la oración fúnebre en el Siglo de Oro, véase Cerdán (1985: 89-102).

27. Uno de los sonetos que mejor ejemplifica este hecho es el que Quevedo dedica a Melchor de Bracamonte, donde "mérito", "nobleza», "valor» o "el cargo" expresan encomio y lamento a un tiempo: «Sin ti quedó la guerra desarmada, / y el mérito agraviado sin consuelo; / la nobleza y el valor, en llanto y duelo, / y la satisfacción mal disfamada. / [...] / El cargo que en el mundo no alcanzaste/ es el que yace, el huérfano y el triste, / que tú, de su desdén, te coronaste» («Melpómene», "Túmulo de Melchor de Bracamonte», 13; vv. 5-8, 12-14).

28. Este el caso, por ejemplo, del tercero de los sonetos que Quevedo dedica al duque de Osuna en la musa «Melpómene», en el que son sus soldados los que atestiguan con su llanto la bonhomía de su capitán: «Lágrimas de soldados han deshecho / en mí las resistencias de diamante; / yo cierro al que el ocaso y el levante / a su victoria dio círculo estrecho» (Quevedo, «Epitafio del duque de Osuna», 7; vv. 5-8).

29. Los tercetos se convierten así en un ejemplo de reducción no perifrástica, que sirve para mover los afectos y que se puede relacionar con la imitación del epigrama de origen antiguo de este tipo de sonetos: $«_{i} Y$ a tanto vencedor venció un proceso! / De su desdicha su valor se precia: / murió en prisión, y, muerto, estuvo preso» («Melpómene», «Túmulo del duque de Osuna», 5; vv. 12-14). 
nuación del poema que nos ocupa. A diferencia de los epitafios panegíricos, en los que los sonetos van del elogio al consuelo o al lamento, introduciendo algún tipo de consideración moral, estos dos sonetos tienden a un esquema bipartito $^{30}$. Tal y como hemos mencionado en este trabajo, los cuartetos caracterizan al difunto por su condición y acciones, mientras que los tercetos presentan su muerte como una especie de condena divina. Quevedo parece darnos a entender así cómo actúa la justicia divina con aquellos seres que, como Gustavo Adolfo, muestran una ambición desmedida y contravienen el dogma cristiano:

Rayo ardiente del mar helado y frío,

y fulminante aborto, tendí el vuelo;

incendio primogénito del yelo,

logré las amenazas de mi brío.

[...]

Y bala providente y vengadora,

burlando de mi arnés, defensa vana,

me trujo negro sueño y postrer hora.

(Quevedo, «Túmulo de Gustavo Adolfo de Suecia», 25; vv. 1-4, 9-11)

La disposición bipartita del soneto para Gustavo Adolfo de Suecia, o del dedicado al duque de Wallenstein, sustituyen la exposición de hechos (narratio) de los sonetos de carácter laudatorio por el desarrollo de un argumento que pasa de dos hechos concretos - las muertes de Adolfo V de Suecia y de Wallenstein- a una reconvención moral y religiosa de carácter general ${ }^{31}$, organización esta en la que el soneto de Quevedo se muestra muy cercano a la segunda versión del lopesco. Lo más novedoso con respecto a la estructura de la tradición funeral radica en la idea de que la ambición e impiedad por las que debe ser recordado el difunto son las que le causan la muerte y motivan su reflexión final sobre la vanidad del mundo ${ }^{32}$.

30. Para esta estructura bipartita en los sonetos de Quevedo, véanse, entre otros, García Berrio (1982: 261-294) y Pozuelo (1999: 249-268).

31. En los cuartetos del soneto destinado a Wallenstein, Quevedo caracteriza al duque de Bohemia como un ser vil y despreciable, que traicionó a su emperador Fernando II, y considera cierta la sospecha de que Wallenstein planeaba asesinar a Fernando II de Habsburgo. La lectura moral ilustra cómo ningún hombre ha de olvidar que la mezquindad y el intento de revelarse contra su señor recibe el castigo que merece: «Más soberbio y aleve que guerrero, / al reino de Bohemia puso escalas, / la elección de su cetro dio a las balas, / y esperó la corona del acero. [...] No se ve el hombre, vense las heridas; / del cuerpo muerto nacen escarmientos: / tú los quieres crecer si los olvidas» (Quevedo, «Monumento a Wollistán», 26; vv. 5-8, 12-14). Germán Vega García-Luengos (2002: 793-827), que atribuye a Calderón de la Barca la comedia El prodigio de Alemania, explica algunas de las consecuencias que la traición de Wallenstein originó a nivel literario.

32. La muerte del rey sueco se asemeja así con la caída de un tirano que trata de imponer su autoridad sobre un conjunto de hombres. Aftonio (Ejércicios de retórica, 235): «Si es una ley honrar a quienes liberan la patria, solo resta castigar a quienes la esclavizan [...] Será útil que caiga el tirano, pues hará que las leyes permanezcan». 
De hecho, un estudio del ornatus del poema confirma cómo la mayor parte de los tropos y figuras inciden sobre la caracterización de Gustavo Adolfo de Suecia y las consecuencias que se desprenden de su conducta ${ }^{33}$. Uno de los procedimientos que más llama la atención es el de la antítesis, que sirve tanto para referirse a los orígenes nórdicos del monarca y al poder de sus ejércitos («rayo ardiente», «mar helado y frío», v. 1, «incendio» «yelo», v. 3), como para reforzar la vanidad de la existencia, ejemplificada en este caso por la insignificancia de las victorias del rey sueco una vez que ha muerto y condenado su alma al infierno: «el que los pierde, ¿qué victorias gana?» (v. 14). Las metonimias, que apelan al difunto o a Dios, tienen una función semejante; con ellas, Quevedo tiende a evitar designar directamente a estos seres e incide en los atributos que les otorga en el poema ${ }^{34}$. A Gustavo Adolfo se refiere en el verso 1 con la tópica metonimia de «rayo», que suele identificar a Júpiter por ser el arma empleada por el Dios para fulminar a sus enemigos, como hemos visto en el soneto de Lope. Su uso crea un efecto hiperbólico y está asociado al enaltecimiento del ardor guerrero de monarcas que, como el sueco, son prototipos de rey soldado. En el segundo de los cuartetos (vv. 7 y 8), nos encontramos con otras metonimias de mayor alcance que lo convierten en "azote del cielo", por el peligro que suponían sus tropas para el orden establecido por los ejércitos cristianos en Europa, y en «terror del augusto señorío", por el pánico que infundía el poder destructivo de sus tropas en su avance por territorio germano. «Del cielo» es metonimia muy habitual de Dios, e indica cómo esta deidad rige todo cuanto sucede en el mundo.

El uso del adjetivo en los tercetos pone de manifiesto como Dios envía la «bala providente y vengadora» (v. 9) que hace inútil la protección del "arnés» de Gustavo Adolfo («defensa vana» v. 10), y se convierte en «venganza soberana» (v. 12) por la herejía de sus campañas ${ }^{35}$. La adjetivación del soneto ahonda también en los aspectos estructurales y de estilo señalados. En el primer cuarteto contribuyen a la caracterización del monarca con una rápida sucesión de opuestos: «ardiente», «helado y frío»; «fulminante», «primogénito», mientras que en los ter-

33. El ornatus es la virtud más importante de la elocutio para el examen del estilo literario; consta de dos formantes básicos: la elección de palabras (tropos y figuras) y su combinación (compositio). 34. Ambos recursos ofrecen variadas posibilidades expresivas y conceptuales a la hora de caracterizar a los fallecidos o de referirse a cuestiones más convencionales de la tradición funeral, como la tumba o el cadáver.

35. Un estudio del papel que desempeña el adjetivo en Quevedo debe tomar como base los planteamientos estructurales y semánticos propuestos por María José Tobar Quintanar (1997: 46-47), que analiza su función dentro de la poesía moral. La autora indica que se debe tener en cuenta la relación directa que establece el adjetivo con el sustantivo, su relación indirecta en el interior de la cláusula, el contexto poemático en el que se inserta, los distintos moldes estróficos en los que se integra, así como las implicaciones que estos aspectos muestran en la faceta semántica o en la demostración de ingenio verbal en cada caso concreto. Para el estudio del adjetivo en la poesía de Quevedo pueden verse, entre otros, Pozuelo (1979: 241-279), centrado en la lírica amorosa, Ariza (1984: 33-44) y Roig Miranda (1989: 318-319, 326-327). 
cetos subrayan la lectura moral que Quevedo hace de la muerte del monarca, para el que no hay posibilidad de redención ni de vida eterna: «negro sueño y postrer hora» (v. 11). Todos ellos favorecen, además, la agilidad y el ritmo, que puede que sea uno de los aspectos de estilo más destacados del soneto para Gustavo Adolfo, y que demuestra el dominio que tiene el poeta de esta estrofa. En el primer cuarteto, la combinación del polisíndeton y el fenómeno de la correlación le permite acumular hechos y cualidades del rey de una manera muy dinámica ${ }^{36}$. A ello contribuye el uso coordinado de tres adjetivos («helado y frío, / y fulminante») y la yuxtaposición del tercero ("primogénito»); de este modo, la asimetría de los versos del isocolon les proporciona dinamismo y agilidad, ejemplificando la velocidad con la que irrumpe el monarca sueco Gustavo Adolfo en la Europa continental.

En este y en otros muchos sonetos de Quevedo, Lope o Góngora, la reiteración del polisíndeton genera períodos fundamentalmente por correlación que aceleran el ritmo del poema y precipitan la conclusión. Semánticamente suelen tener, como en el caso del de Gustavo Adolfo, la forma ascendente del incrementun, que refuerzan anáfora, paralelismo y correlación progresiva («alma y cuerpo») ${ }^{37}$ :

\section{Y despojo a venganza soberana}

alma y cuerpo; me llora quien me llora;

el que los pierde, ¿qué victorias gana?

(Quevedo, «Túmulo de Gustavo Adolfo de Suecia», 25; vv. 25: 12-13)

Como se puede advertir, el polisíndeton y el fenómeno de la correlación favorecen la amplificación por congenieres (acumulación) típica de los elogios, que permite condensar una gran cantidad de ideas, dotar de gran energía a la expresión para apelar a los afectos y generar una agradable armonía verbal. Gracias a ello, Quevedo condensa en muy pocos versos gran cantidad de hechos y acciones sobre la vida del difunto: orígenes, conquistas, muerte y reflexión moral, que, sin alterar notablemente el ritmo, aportan dinamismo y cierta variedad a la lectura.

Otros recursos de estilo presentes en el soneto son la aliteración y la prosopopeya. La aliteración de consonantes vibrantes transmite dureza al pasaje y contrastan, en el caso de «terror», con la quietud de las consonantes sordas; este fenómeno se vincula al ardor guerrero de Gustavo Adolfo y a su fuerza; como se

36. En el soneto se utiliza la conjunción copulativa en nueve ocasiones. El término de correlación fue acuñado por Dámaso Alonso y Carlos Bousoño (1970: 21-74).

37. Quevedo repite de este modo procedimientos estilísticos parecidos a los de su prosa sobre los que Antonio Azaustre (1996: 75) considera: «La sinonimia suele tener en la mayoría de los pasajes la forma ascendente del incrementum. Figuras del campo de la repetitio, como la anáfora y el polisindeton, aportan un importante refuerzo que los destaca aún más. La finalidad retórica de estas trimembraciones se bifurca en las dos vertientes señaladas a propósito de las bimembres: aportación rítmica e intensificación expresiva». Dámaso Alonso (1970: 54-77) distingue dentro de este concepto general entre correlación progresiva (diferentes contenidos conceptuales de sus constituyentes) y correlación reiterativa (idénticos contenidos conceptuales) que se pueden combinar en un mismo texto. 
sabe, el recurso es muy propio de pasajes épicos en los que se describe la fortaleza desmesurada de los héroes en el campo de batalla ${ }^{38}$ :

Rayo ardiente del mar helado y frío,

y fulminante aborto, tendí el vuelo

[...]

azote permitido fui del cielo

y terror del Augusto señorío

(Quevedo, «Túmulo de Gustavo Adolfo de Suecia», 25; v. 1-2, 7-8)

Por último, dentro del análisis del estilo resta por destacar que, a diferencia de lo que ocurría en el soneto de Lope, en el de Quevedo es el ente fantasmal de Gustavo Adolfo el que rememora en el poema su existencia terrena y su muer$t^{39}$. Este tipo de voz sepulcral es muy habitual en las composiciones de carácter funeral en las que el difunto toma la palabra para proporcionarle un tono más vivencial e íntimo al discurso. García Jiménez (1994: 16) considera que este tipo de técnica, unida a descripciones, visiones y prosopopeyas, sirve para aumentar la tensión en las elegías castellanas medievales: «Así, la figura del finado, en cuya memoria se entona el planto, y el contenido moral, generalmente religioso, llegan inequívocamente al receptor».

Todos estos aspectos inscriben el soneto para Gustavo Adolfo de Suecia en la línea épica del epigrama y la elegía de origen antiguo, que trasladó tópicos y motivos a la historiografía, a la hagiografía, a la materia caballeresca romance..., dentro de un modelo poético e ideológico marcado por la condena de un monarca contrario a la virtud. La caracterización de Gustavo Adolfo va a condicionar la construcción retórica del poema. Su fuerza, ambición o vileza son incomparables y merecen ser recordadas, para que cualquier otro gobernante comprenda lo que le puede pasar si desafía la voluntad de Dios. Los cuartetos comprenden la caracterización del monarca, mientras que los tercetos narran su muerte, que presentan como una consecuencia de la impiedad de las acciones del sueco. Los recursos de estilo resaltan estos dos aspectos: metonimias, antítesis y correlaciones

38. Estos cuartetos, marcados por la caracterización épica del monarca, también utilizan imágenes de carácter hiperbólico que son muy propias en la descripción de acciones bélicas: «crecíle, y calenté con sangre el suelo» (v. 6). Quevedo utiliza esta expresión en otro de los sonetos de "Melpómene»: «con sangre calentó, creció con llanto» (Quevedo, «Inscripción en el túmulo del duque de Osuna», 5; v. 4) o en la silva "Roma Antigua y moderna»: "con sangre le mancharon; / le crecieron con llanto" (vv. 30-31). En Virgilio (Eneida, x, 452) encontramos un motivo muy parecido: «frigidus Arcadibus coit in praecordia sanguis».

39. Heinrich Lausberg (1975: $\$ \$ 826-829)$ establece un vínculo entre fictio personae y evidentia por sermocinatio, que es una de las formas fundamentales de esa «impresión de vida» que se logra con este tipo de hablantes. Lausberg $(1975: \$ 826)$ señala además: «La fictio personae es una figura altamente patética nacida de la intensificación de la fantasía creadora. [...] Algunos teóricos mantienen con tesón la distinción entre fictio personae (prosopopeya) y sermocinatio (etopeia) pues la prosopopeya se limita a las cosas irracionales (y a los muertos) mientras que la etopeya afecta a las personas naturales». 
acumulan en la breve extensión del soneto una gran cantidad de aspectos de la figura de Gustavo Adolfo y de sus conquistas; mientras que el valor conceptual de ciertos adjetivos explica su muerte como un castigo de Dios a su vileza ${ }^{40}$. De este modo, este soneto túmulo que Quevedo dirige al rey sueco le sirve para desarrollar su visión de unos hechos históricos a los que también se refirió en sus obras políticas y morales, con la que coinciden otros poetas espańoles de la época, como Lope, y que tuvieron una gran trascendencia en la Europa de su tiempo.

\section{Conclusión}

La comparación de los dos sonetos a Gustavo Adolfo revela que Lope y Quevedo usaron imágenes semejantes para contar el ascenso y caída del rey sueco. Ambos recurren a la imagen del rayo, que sirve tanto para sugerir la rapidez y capacidad destructiva del monarca, que Quevedo relaciona con su origen septentrional, como para evocar el castigo divino que le espera: la bala de arcabuz actúa como un rayo de Júpiter, que elimina al arrogante sueco del mismo modo que el rey de los dioses acabó con el soberbio Faetón o con los gigantes, subtexto este que elige evocar más abiertamente Lope. Además, los dos sonetos coinciden en subrayar la nefasta influencia del personaje con sangrientas referencias, y la rapidez de su auge y caída con una notable preocupación por el ritmo del poema. Por último, los dos ingenios aprovechan el castigo de Gustavo Adolfo para llevar a cabo una reflexión general, que en Lope se inclina más a lo político, y en Quevedo más a lo moral.

$\mathrm{Al}$ mismo tiempo, los sonetos presentan algunas diferencias formales. $\mathrm{La}$ principal está en el punto de vista, pues Lope elige un narrador en tercera persona y se fija más en los efectos de las acciones de Gustavo Adolfo según las contemplan sus enemigos. Por el contrario, Quevedo elige un punto de vista más empático y, a la vez, más entroncado en la tradición del epitafio: en su soneto nos interpela directamente el difunto, aunque esto no quiere decir que el poeta se identifique con él, pues Quevedo deja muy claro que Gustavo Adolfo sufre el castigo divino por su arrogancia y crueldad. De hecho, Quevedo se muestra menos preocupado por el decoro debido a la figura real que Lope, que mostró ese afán tanto en la epístola citada arriba como en los cambios que efectuó en su soneto entre 1632 y 1634.

Llama la atención el contraste entre la imagen claramente negativa de Gustavo Adolfo que presentan estos sonetos y la idea que proporciona la crítica acerca de la recepción de la figura del monarca sueco en la España áurea. Como hemos visto arriba, críticos como Clavería (1952) y, más recientemente, Oostendorp (1989) y Corredera Nilsson (2009) insisten en que los espańoles del momento vieron la muerte de Gustavo Adolfo con una sorprendente ecuanimidad que lleva-

40. La mayor parte de los sonetos de «Melpómene» se hacen eco de hechos históricos que el poeta reelabora artísticamente en base a su conocimiento del pasado, a la concepción heroica de la poesía funeral y a sus propias convicciones personales. Otros detalles en Llamas Martínez (2012). 
ba a dichos críticos a reconocer las obvias virtudes del rey sueco. Desde luego, esta visión no funciona en los sonetos que hemos analizado, por mucho que críticos como Clavería hayan intentado extenderla a ellos. Ya hemos visto cómo este estudioso leía erróneamente el poema de Lope, y otro tanto ocurre cuando se enfrenta a los textos de Quevedo, en este caso una carta en la que el poeta da noticia de la muerte de Gustavo Adolfo y el soneto consabido. En la primera, Clavería entiende que "Quevedo juzga la vida del rey como descarrío, y su muerte como ejemplo, pero de la pluma de don Francisco sale la figura de Gustavo Adolfo engrandecida, y los sentimientos de los españoles hacia él purificados de rencor y animados de respeto por el rey caído» (1952: 13), y en el segundo percibe también una grandeza en la figura del monarca que no percibimos en el texto: «Poco después de esta epístola debió [de] escribir su soneto al rey de Suecia, en que el propio Gustavo habla desde más allá de la muerte como un cristiano desengañado de la vanidad de sus victorias y de su vida, al igual que pudiera hacerlo cualquier español del Seiscientos» (1952: 13). Si en estos textos Gustavo Adolfo tiene grandeza, es solo satánica, y si habla «al igual que pudiera hacerlo cualquier español del Seiscientos», sería como cualquiera que hable desde el infierno y cuyo pecado y castigo sirva como ejemplo moral. Es decir, en esas opiniones los críticos se dejan arrastrar por sus deseos de mostrar unas relaciones hispano-suecas más amables de lo que fueron en el siglo XVII, o incluso por su punto de vista favorable a la figura de Gustavo Adolfo, pero no, desde luego, por el claro tono negativo de los poemas. Ignoramos si, como afirman Oostendorp y Corredera Nilsson, la visión del monarca sueco es favorable en los textos teatrales e históricos, y por tanto los poemas de Lope y Quevedo representan una excepción, tal vez determinada por el género. Lo cierto es que las conclusiones de los críticos citados no pueden extenderse a todos los textos áureos, pues incluso textos político-morales en prosa como las Empresas políticas de Diego Saavedra Fajardo ven la muerte de Gustavo Adolfo de modo muy parecido al de los sonetos analizados. Es más, en la empresa 88 («Volentes trahimur») Saavedra Fajardo llega a utilizar una imaginería emparentada con la de los poemas:

¡Qué armado de amenazas sale el rayo entre las nubes! En la resistencia descubre su valor. Sin ella se deshace en el aire. Así fue aquel de Suecia engendrado de las exhalaciones del Norte. En pocos días triunfó del imperio y llenó de temor el mundo, y en una bala de plomo se desapareción ${ }^{41}$. (938)

El parecido con los sonetos resulta notable, tanto en el tono como en las imágenes (el rayo, el clima tempestuoso, el asombro y temor del mundo, la bala) e, incluso, en la reflexión general, que nos recuerda a la de Lope. Para explicarlo no necesitamos postular que Saavedra Fajardo conociera los sonetos (tampoco podemos descartarlo), pues podría ser también que los tres textos se hicieran eco

41. Otras referencias de las Empresas politicas a Gustavo Adolfo, siempre negativas, se encuentran en las empresas 74 (836), 81 (889) y 92 (963). 
de un sentimiento e imágenes comunes en el Madrid del momento. En cualquier caso, el texto de Saavedra Fajardo nos recuerda que tenemos que ser precavidos al juzgar el tono de este tipo de sonetos funerales a monarcas percibidos como nefastos. No podemos leer los sonetos de Lope y Quevedo como favorables, ni siquiera ambiguos, ante la figura de Gustavo Adolfo. Sin embargo, el decoro y el cauce genérico les exige llevar a cabo una reflexión general final, ya moral, ya de otro orden, que eleve el caso presentado a la categoría de ejemplo universal. 


\section{Bibliografía}

Aftonio, Ejercicios de retórica, ed. Ma Dolores Reche Martínez, Madrid, Gredos, 1991, 207-273.

Alexiou, Margaret, The Ritual Lament in Greek Tradition, Cambridge, University Press, 1974.

Alonso Veloso, María José, «La poesía de Quevedo no incluida en las ediciones de 1648 y 1670: una propuesta acerca de la ordenación y el contenido de la 'Musa décima'», La Perinola, 12 (2008), 269-334.

Alonso, Dámaso, y Bousoño, Carlos, Seis calas en la expresión literaria española: prosa, poesía, teatro, Madrid, Gredos, 1970.

Antología palatina. La guirnalda de Filipo, ed. Guillermo Galán Vioque, Madrid, Gredos, 2004.

Arellano, Ignacio, «El poema 167 de Tomé de Burguillos. Paravicino, Gustavo Adolfo de Suecia, Felipe IV y otras notas", Nueva Revista de Filología Hispánica 59 (2011), 447-466.

-, El ingenio de Lope de Vega. Escolios a las Rimas humanas y divinas del licenciado Tomé de Burguillos, New York, Idea, 2012.

Ariès, Philippe, El hombre ante la muerte, trad. Mauro Armiño, Madrid, Taurus, 1983.

ArIzA, Manuel, «Aspectos de la adjetivación en Quevedo», en Quevedo en su centenario, ed. Ricardo Senabre, Cáceres, Ministerio de Cultura, 1980, 9-23.

Astrana Marín, Luis (ed.), Epistolario completo de D. Francisco de QuevedoVillegas, Madrid, Instituto Editorial Reus, 1946.

Ávila y ZúNíga, Luis de, Comentario de la guerra de Alemania, Amberes, Juan Steelsio, 1550.

Azaustre Galiana, Antonio, «La apóstrofe en los sonetos satíricos de Quevedo», en Diálogo y retórica, coord. Antonia Víñez Sánchez, Cádiz, Universidad de Cádiz, 1996b, 87-96.

-, Antonio, Paralelismo y sintaxis del estilo en la prosa de Quevedo, Santiago de Compostela, Universidade de Santiago de Compostela, 1996a.

Camacho Guizado, Eduardo, La elegía funeral en la poesía española, Madrid, Gredos, 1969.

Candelas Colodrón, Manuel Ángel, «La poesía religiosa de Quevedo: los 'Sonetos sacros'», Bulletin of Spanish Studies, 83, 5 (2006), 637-667.

Carreño, Antonio (ed.), Lope de Vega Carpio, Rimas humanas y divinas del licenciado Tomé de Burguillos, Salamanca, Almar, 2002.

Carvallo, Luis Alfonso de, Cisne de Apolo, ed. Alberto Porqueras Mayo, Kassel, Reichenberger, 1997.

Cerdán, Francis, «La oración fúnebre del Siglo de Oro. Entre sermón evangélico y panegírico poético sobre fondo de teatro", Criticón, 30 (1985), 78-102.

Cerdón, Francis (ed.), Hortensio de Paravicino, Sermones cortesanos, Madrid, Castalia, 1994. 
Claudiano, Claudio, Poemas, ed. Miguel Castillo Bejarano Madrid, Gredos, 1993.

Clavería, Carlos, "Gustavo Adolfo y Cristina de Suecia, vistos por los españoles de su tiempo", Clavileño, 4 (1952), 11-16.

Corredera Nilsson, Enrique J., "Todos somos godos»: las relaciones hispano-suecas desde 1640 hasta la Paz de Oliva, Madrid, Universidad Complutense, 2009.

Cuiñas Gómez, Macarena (ed.), Lope de Vega Carpio, Rimas humanas y divinas del licenciado Tomé de Burguillos, Madrid, Cátedra, 2008.

Curtius, Ernst Robert, Literatura europea y Edad Media latina,México, Fondo de Cultura Económica, 1981-1984 (reimp.).

Estévez Molinero, Ángel, "Género y modalidad elegíaca en el funeral del siglo XviI», en La elegía, coord. Begoña López Bueno, Sevilla, Universidad de Sevilla, 1996, 261-292.

Ferraté, Gabriel, Líricos griegos arcaicos, Barcelona, Sirmio, 1991.

García Aguilar, Ignacio, «El soneto de Lope a la muerte de Enrique IV: variantes de autor y reescritura entre 1610 y 1627», Caliope, 15, 2009, 63-84.

García Berrio, Antonio, «Definición macroestructural de la lírica amorosa de Quevedo, un estudio de forma interior en los sonetos», en Homenaje a Quevedo: Actas de la II Academia Literaria Renacentista, Universidad de Salaman$c a$, ed. Víctor García de la Concha, Salamanca, Caja de Ahorros y Monte de Piedad de Salamanca, 1982, 261-294.

García Jiménez, María Emilia, La Poesía elegíaca medieval en lengua castellana, Logroño, Instituto de Estudios Riojanos, 1994.

Gentili, Bruno, Poesía y público en la Grecia antigua, trad. Xavier Riu, Barcelona, Quaderns Crema, 1996.

Hermógenes, Ejercicios de retórica, ed. Ma Dolores Reche Martínez, Madrid, Gredos, 1991, 165-205.

Jauralde, Pablo, Francisco de Quevedo (1580-1645), Madrid, Castalia, 1999.

Jover, José María, 1635. Historia de una polémica y semblanza de una generación, Madrid, CSIC, 1949.

Kantorowicz, Ernst H., Los dos cuerpos del rey: un estudio de teología politica medieval, trad. Susana Aikin Araluce y Rafael Blázquez Godoy, Madrid Alianza Editorial, 1985.

LAUSBERG, Heinrich, Elementos de retórica literaria: introducción al estudio de la filología clásica, románica, inglesa y alemana, Madrid, Gredos, 1975.

León Pinelo, Antonio de, Anales de Madrid (desde el año 447 al de 1658), ed. Pedro Fernández Marín, Madrid, Instituto de Estudios Madrileńos, 1971.

Libro de Buen Amor, ed. Alberto Blecua, Madrid, Cátedra, 1992.

Livio, Tito, Ab Urbe condita, ed. RobertusSeymoutConway y Stephanus KeymerJohnsen, Oxford, University Press, 1964.

Llamas Martínez, Jacobo, "Reescritura de elogio, lamento y consuelo en los sonetos funerales de Lope, Góngora y Quevedo», Cuadernos Aleph, 4 (2012), 110-145. 
López Poza, Sagrario, «La difusión y recepción de la 'Antología Griega' en el Siglo de Oro", en En torno al canon, aproximaciones y estrategias: VII Encuentro Internacional sobre Poesía del Siglo de Oro, coord. Begoña López Bueno, Sevilla, Universidad de Sevilla, 2005, 15-68.

Matas Caballero, Juan (ed.), «Epitafios a don Rodrigo Calderón: del proceso sumarísimo al sumario tópico-literario del proceso» en Silva studia philologica in honorem Isaias Lerner, coord. Isabel González-Renieblas y Juan Carlos Mercado, Madrid, Castalia, 2001, 433-455.

Maura Gamazo, Gabriel (duque de Maura), Vida y reinado de Carlos II, Madrid, Espasa-Calpe, 1954.

Mena, Juan de, Laberinto de Fortuna, ed. Maxim P.A.M. Kerkhof, Madrid, Castalia, 1995.

Menandro, Dos tratados de retórica epidíctica, ed. Fernando Gascó, Manuel García García y Joaquín Gutiérrez Calderón, Madrid, Gredos, 1996.

Nieto Soria, José Manuel, «Apología y propaganda de la realeza en los cancioneros castellanos del siglo xv: Diseño literario de un modelo político», España medieval, 11 (1988), 185-221.

Oostendorp, Henk, "Cristina de Suecia en el teatro español del siglo XVII», Diálogos hispánicos 8.2 (1989), 245-259.

Peraita, Carmen, «Apacible brevedad de los renglones, abreviada vida de monarcas: Ana de Castro Egas, Francisco de Quevedo y la escritura del panegírico regio", La Perinola, 9 (2005), 151-170.

Pérez de Guzmán, Fernán, Generaciones y semblanzas, ed. José Antonio Barrio Sánchez, Madrid, Cátedra, 1998.

Pernot, Laurent, La Rhétorique de l'éloge dans le monde gréco-romain, Paris,Inst itutd'EtudesAugustiniennes, 1993.

Ponce Cárdenas, Jesús, «El epitafio hispánico en el Renacimiento: textos y contextos", e-Spania, http://e-spania.revues.org/23300; DOI : 10.4000/espania.23300 [consultado el 1 de abril de 2014].

Pozuelo Yvancos, José María, «La construcción retórica del soneto quevediano", La Perinola, 3 (1999b), 249-268.

—, El Lenguaje poético de la lírica amorosa de Quevedo, Murcia, Universidad, 1979.

Pulgar, Fernando del, Claros varones de Castilla, ed. Miguel Ángel Pérez Priego, Madrid, Cátedra, 2007.

Quevedo y Villegas, Francisco de, El parnaso español, Madrid, a costa de Pedro Coello, 1648.

—, Poesia moral (Polimnia), ed. Alfonso Rey, Madrid, Támesis, 1999.

Quintiliano, Marco Fabio, Institution oratoire, Paris, Les belles lettres, 6 vol., 1975-1980.

Race, William H., Classical Genres and English Poetry, London / New York / Sydney, Croom Helm, 1988.

Rodríguez Adrados, Francisco, El mundo de la lírica griega antigua, Madrid, Alianza, 1981. 
Roig Miranda, Marie, Les Sonnets de Quevedo: variations, constance, évolution, Nancy, Presses Universitaires de Nancy, 1989.

Rosales, Luis y Luis Felipe Vivanco (eds.), Poesía heroica del imperio, vol. II, Madrid, Jerarquía, 1943.

Rozas, Juan Manuel y Jesús Cañas Murillo (eds.), Lope de Vega Carpio, Rimas humanas y divinas del licenciado Tomé de Burguillos, Madrid, Castalia, 2005.

Saavedra Fajardo, Diego, Empresas politicas, ed. Sagrario López Poza, Madrid, Cátedra, 1999.

Salustio Crispo, Cayo, A conxuración de Catilin. A guerra de Iugurta, ed. Xosé Martínez García, Vigo, Editorial Galaxia, 2006.

Schwartz, Lía, «La transmisión renacentista de la poesía grecolatina y dos sonetos de Quevedo ('Parnaso', 'Erato', XXXVIII y XXXIX)", Edad de Oro, 12 (1993), 303-320.

Schwartz, Lía, y Arellano, Ignacio (eds.), Un Heráclito cristiano, canta sola a Lisi y otros poemas de Quevedo, Crítica, Barcelona, 1998.

Tobar Quintanar, María José, El Adjetivo en la obra de Quevedo: poesía y prosa morales, Santiago de Compostela, Tesis Doctoral, 1997.

Vega Carpio, Lope de Vega, Epistolario, ed. Agustín G. de Amezúa, vol. 4, Madrid, Real Academia Española, 1989.

-, Rimas humanas y divinas del licenciado Tomé de Burguillos, ed. Antonio Carreño, Salamanca, Almar, 2002.

Vega García-Luengos, Germán, "Calderón y la política internacional: las comedias sobre el héroe y traidor Wallenstein», en Calderón de la Barca y la España del Barroco, coord. José Alcalá-Zamora y Ernest Belenguer Cebrià, Madrid, Centro de Estudios Políticos y Constitucionales, Sociedad Estatal España Nuevo Milenio, 2001, vol. 2, 793-827.

Virgilio Marón, Publio, Eneida, ed. Luis Rivero García, Madrid, CSIC, 2009-2010. 
